\begin{tabular}{lll}
\hline Jurnal Teknologi Kimia Unimal & $\begin{array}{l}\text { Jurnal } \\
\text { Teknologi } \\
\text { Kimia } \\
\text { http://ojs.unimal.ac.id/index.php/jtk }\end{array}$ & $\begin{array}{l}\text { Kimimal } \\
\text { Unimal }\end{array}$ \\
\hline
\end{tabular}

\title{
PENGARUH WAKTU EKSTRAKSI DAN KONSENTRASI HCI UNTUK PEMBUATAN PEKTIN DARI KULIT JERUK BALI
}

\section{(Citrus maxima)}

\author{
Amri Aji, Syamsul Bahri, Tantalia \\ Jurusan Teknik Kimia, Fakultas Teknik, Universitas Malikussaleh \\ Kampus Utama Cot. Tengku Nie Reulet, Muara Batu, Aceh Utara- 24355. \\ email: amriaji_bandardua@yahoo.co.id
}

\begin{abstract}
Abstrak
Pektin adalah senyawa polimer yang dapat mengikat air, membentuk gel atau mengental cairan. Sifat inilah yang dapat dimanfaatkan sehingga selain untuk jelly, pektin juga dipakai dalam industri daging dan produk pangan lainnya yang membutuhkan pengikat air. Pektin dapat dihasilkan dari bahan yang banyak mengandung pektin seperti kulit jeruk bali. Kulit jeruk bali terdapat senyawa alkaloid, likopen, Vitamin $C$, serta yang paling dominan adalah pektin. Pektin dalam kulit jeruk bali dalam dimanfaatkan dengan ekstraksi menggunakan pelarut. Kulit jeruk bali diblender sampai halus dan ditimbang sebanyak 100 gram, $\mathrm{HCl}$ sebanyak $300 \mathrm{ml}$ dengan konsentrasi 0,1N dimasukan ke dalam labu Takar $500 \mathrm{ml}$ kemudian diekstraksi selama 70 menit pada suhu $80^{\circ} \mathrm{C}$ serta direndam selama 12 menggunakan etanol 96\%. Kemudian disaring dan filtarnya diambil untuk dianalisis \% yield, kadar air, akadar abu, asam galakturanat dan mektoksil dari bahan baku kulit jeruk bali. Selanjutnya diteruskan untuk waktu 80, 90, 100, dan 110 menit, kosentrasi $\mathrm{HCl} 0,15 \mathrm{~N}, 0,20 \mathrm{~N}, 0,25 \mathrm{~N}$, dan 0,30 N dengan suhu tetap $80{ }^{\circ} \mathrm{C}$. Hasil penelitian menunjukkan bahwa \% yield Pektin dari kulit jeruk bali meningkat dengan meningkatnya waktu ektraksi sampai waktu 90 menit setelah waktu tersebut \%yield pektik mulai menurun. Kadar Air menurun dengan meningkatnya waktu etraksi dan konsentrasi pelarut. Sedangkan kadar asam galakturonat dan metoksil meningkat dengan meningkat waktu ektrasi dan konsentarai pelarut Persen yield pektin tertinggi didapat pada waktu etraksi 90 menit dengan konsentrasi pelarut etanol 0,25 N \% Yield 49,76\% sedangkan \% yield terendah 30,27\% pada konsentrasi pelarut 0,1 N. Asam galakturonat tertinggi didapat pada waktu 110 menit sebesar 65,961\% dengan kosentrasi pelarut 0,25 N sedangkan terendah pada waktu ektraksi 70 menit dengan persen asam galakturonat 4,268\%. Kadar metoksil terendah 0,434\% dan tertinggi 5,5\% dengan konsentrasi pelarut $0,1 \mathrm{~N}$ dan $0,30 \mathrm{~N}$ dan waktu 70 menit dan 110 menit.
\end{abstract}

Kata kunci: ekstraksi, pektin, galakturonat, metoksil

\section{Pendahuluan}

Jeruk bali merupakan tanaman asli Indonesia tetapi karena rasanya yang agak getir dan kulit buahnya lebih tebal sehingga kurang disukai konsumen. 
Produksi jeruk bali di berbagai daerah di Indonesia mencapai 110.000 ton per tahunnya dan hampir 50\% kulit jeruk yang dihasilkan belum termanfaatkan (Diah,2015).

Salah satu manfaat kulit jeruk adalah untuk membuat pektin. Pektin adalah senyawa polimer yang dapat mengikat air, membentuk gel atau mengentalkan cairan. Sifat inilah yang dapat dimanfaatkan sehingga selain untuk jelly, pektin juga dipakai dalam industri daging dan produk pangan lainnya yang membutuhkan pengikat air.

Selama ini, untuk mencukupi kebutuhan pektin dalam negeri, Indonesia masih mengimpor pektin. Indonesia merupakan negara pengimpor dan pemakai pektin yang cukup besar. Banyak industri di Indonesia yang menggunakan pektin, mulai dari industri makanan dan minuman hingga industri tekstil. Oleh karena itu perlu adanya usaha untuk menghasilkan pektin. Sehingga peneliti tertarik untuk mengetahui seberapa besar kandungan pektin yang ada di dalam kulit jeruk bali, setidaknya dengan memanfaatkan kulit jeruk bali sebagai bahan baku pembuatan pektin dapat mengurangi impor pektin dan sekaligus memanfaatkan kulit jeruk bali yang belakangan ini sudah mulai kurang populer di kalangan masyarakat menjadi sesuatu yang bernilai ekonomis lebih tinggi.

Jeruk bali (Citrus maxima) merupakan tanaman buah yang mengandung banyak komponen nutrisi yang terkandung di dalamnya. Sebagian besar komponen jeruk bali terletak pada kulitnya, di antaranya terdapat senyawa alkaloid, flavonoid, likopen, vitamin C, serta yang paling dominan adalah pektin dan tanin. Citrus maxima adalah tumbuhan menahun (perennial) dengan karakteristik tinggi pohon 5-15 meter. Batang tanaman agak kuat, garis tengah 10 -30 meter, berkulit agak tebal, kulit bagian luar berwarna coklat kekuningan, bagian dalam berwarna kuning. Pohon jeruk mempunyai banyak cabang yang terletak saling berjauhan dan merunduk pada bagian ujungnya. Cabang yang masih muda bersudut dan berwarna hijau, namun lama-lama menjadi berbentuk bulat dan berwarna hijau tua. Tajuk pohon agak rendah dan tidak teratur. Klasifikasi ilmiah jeruk bali yaitu; Kerajaan Plantae Divisi, Magnoliophyta. 
Kelasnya yaitu; Magnoliopsida Ordo, Sapindales Famili, Rutaceae Genus, Citrus dan spesies C. grandis, C. maxima.

Pektin adalah senyawa polisakarida kompleks yang yang terdapat dalam dinding sel tumbuhan dan dapat di temukan dalam berbagai jenis tanaman pangan. Pektin pertama kali di temukan oleh Vauquelin dalam jus buah pada tahun 1790. Namun saat itu senyawa yang dapat mengentalkan sari buah ini belum diberi nama. Baru setelah pada tahun 1825, Henri Braconnot berhasil mengisolasinya dari tumbuhan, zat yang bermanfaat sebagai perekat dan stabilizer ini di beri nama asam pektat. Wujud pektin hasil ekstraksi adalah berbentuk serbuk berwarna putih agak kecoklat-coklatan. Nama pektin berasal dari kata pectos yang artinya dapat mengental atau menjadi padat.

Pektin tersusun atas asam pektat, asam pektinat dan protopektin. Asam pektat adalah senyawa asam galakturonat yang bersifat koloid dan pada dasarnya bebas dari kandungan metil ester. Asam pektat merupakan senyawa pektin dengan gugus karboksil yang tidak teresterifikasi pada asam galakturonat. Asam pektat bersifat tidak larut dalam air dan tidak membentuk gel. Namun, jika membentuk garam, asam pektat disebut pektat dan dapat larut dalam air (Diah,2015). Asam pektinat adalah asam poligalakturonat yang bersifat koloid dan mengandung sejumlah metil ester. Pektin memiliki derajat netralisasi yang berbeda-beda. Pektinat yang mengandung metil ester yang cukup yaitu lebih dari 50\% dari seluruh karboksil disebut pektin. Pektin ini terdispersi dalam air dan dapat membentuk garam yang disebut garam pektinat. Dalam bentuk garam ini, pektin berfungsi dalam pembuatan jeli dengan keberadaan gula dan asam (Diah,2015).

Protopektin merupakan senyawa-senyawa pektin yang terdapat pada tanaman yang masih muda atau pada buah-buahan yang belum matang. Protopektin tidak larut dalam air. Namun, jika dipanaskan dalam air yang mengandung asam, maka protopektin dapat diubah menjadi pektin dan terdispersi dalam air. Protopektin akan menjadi pektin yang larut dengan adanya hidrolisis asam, secara enzimatis dan secara fisis oleh pemanasan. Hasil dari hidrolisis adalah asam pektinat. Pektin yang dimanfaatkan untuk makanan merupakan suatu polimer yang berisi unit asam galakturonat (sedikitnya 65\%). 
Kelompok asam tersebut bisa dalam bentuk asam bebas, metil ester, garam sodium, kalium, kalsium atau ammonium, dan dalam beberapa kelompok pektin amida. Komposisi kandungan protopektin, pektin, dan asam pektat di dalam buah sangat bervariasi tergantung pada derajat kematangan buah. Pada umumnya, protopektin yang tidak larut itu lebih banyak terdapat pada buahbuahan yang belum matang (Winarno, 1997)

Kandungan pektin dalam tanaman sangat bervariasi, baik berdasarkan jenis tanamannya maupun dari bagian-bagian jaringannya. Bagian kulit dan albedo buah jeruk lebih banyak mengandung pektin daripada jaringan parenkimnya. Struktur dan komposisi kimia pektin tersusun atas molekul asam galakturonat yang berikatan dengan ikatan $\alpha$ - (1-4)-glikosida sehingga membentuk asam poligalakturonat. Gugus karboksil sebagian teresterifikasi dengan metanol dan sebagian gugus alkohol sekunder terasetilasi ditunjukan pada Gambar 1

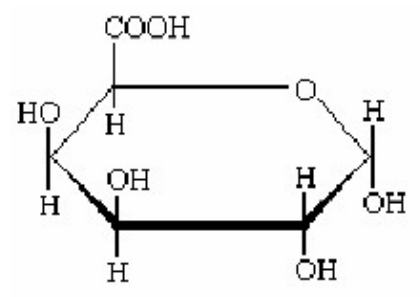

Gambar 1 Struktur Kimia Asam $\alpha$-Galakturonat

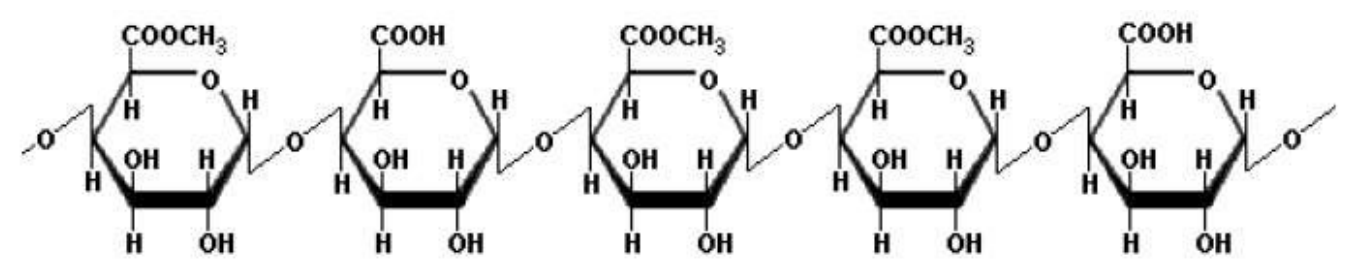

Gambar 2 Struktur Kimia Asam Poligalakturonat

Menurut Hoejgaard (2004), pektin merupakan asam poligalakturonat yang mengandung metil ester. Pektin diekstraksi secara komersial dari kulit buah jeruk dan apel dalam kondisi asam. Masing-masing cincin merupakan suatu molekul dari asam poligalakturonat, dan ada 300-1000 cincin seperti itu 
dalam suatu tipikal molekul pektin, yang dihubungkan dengan suatu rantai linier. Gambar 2 menunjukkan struktur kimia asam poligalakturonat.

Pemisahan pektin dari jaringan tanaman dapat dilakukan dengan cara ekstraksi. Ekstraksi adalah proses perpindahan suatu zat atau solut dari larutan asal atau padatan ke dalam pelarut tertentu. Ekstraksi merupakan proses pemisahan berdasarkan perbedaan kemampuan melarutnya komponenkomponen yang ada dalam campuran. Secara garis besar ekstraksi dibedakan menjadi dua macam, yaitu ekstraksi padat-cair (leaching) dan ekstraksi cair-cair. Ekstraksi padat-cair atau leaching adalah proses pemisahan solut dari padatan yang tidak dapat larut yang disebut inert. Pektin dapat larut dalam beberapa macam pelarut seperti air, beberapa senyawa organik, senyawa alkalis dan asam. Dalam ekstraksi pektin terjadi perubahan senyawa pektin yang disebabkan oleh proses hidrolisis protopektin. Proses tersebut menyebabkan protopektin berubah menjadi pektinat (pektin) dengan adanya pemanasan dalam asam pada suhu dan lama ekstraksi tertentu.

Dua langkah utama dalam proses ekstraksi padat-cair yaitu kontak antara padatan dan pelarut serta pemisahan larutan dari padatan inert. Pelarut yang digunakan dalam proses ekstraksi memiliki syarat utama yaitu dapat melarutkan solut yang terkandung dalam padatan inert. Mekanisme yang berlangsung selama proses ekstraksi padat-cair adalah: Pelarut bercampur dengan padatan inert sehingga permukaan padatan dilapisi oleh pelarut. Terjadi difusi massa pelarut pada permukaan padatan inert ke dalam pori padatan inert tersebut. Laju difusi ini lambat karena pelarut harus menembus dinding sel padatan. Solut yang terdapat dalam padatan melarut dalam pelarut. Campuran solut dalam pelarut berdifusi keluar dari permukaan padatan inert dan bercampur dengan pelarut sisa.

\section{Bahan dan Prosedur}

\subsection{Bahan}

Bahan yang digunakan dalam penelitian ini adalah kulit jeruk bali. Kulit jeruk bali pertama-tama ditimbang seberat 100 gram kemudian dimasukan etanol 
sebanyak $300 \mathrm{~mL}$ dengan konsentrasi 0,1 N kedalam labu ukur $500 \mathrm{~mL}$ dan diekstrasi selama 70 menit pada suhu $80{ }^{\circ} \mathrm{C}$. Kemudian hasil ekstrasi direndam selama 12 jam dengan alcohol 96\% kemudian disaring dan filtratnya diambil untuk di analisis hasilnya persen yied, kadar air, kadar metoksil, dan kadar abu. Kemudian diteruskan untuk waktu ekstrasi 80, 90,100, dan 110 menit dengan variasi konsentrasi pelarut etanol $0,15 \mathrm{~N}, 0,20 \mathrm{~N}, 0,25 \mathrm{~N}$, dan $0,30 \mathrm{~N}$ sedangkan suhu ekstraksi tetap $80{ }^{\circ} \mathrm{C}$.

Analisis hasil penelitian menggunakan persamaan berikut:

1. Persen Yield

Persen Yield $=\frac{a}{b} \times 100 \%$

Keterangan : $\mathrm{a}=$ Berat pektin $($ gram $)$

$$
\mathrm{b}=\text { berat sampel (gram) }
$$

2. Kadar air

$\%$ Air $\quad=\frac{\text { berat sampel awal-berat sampel akhir }}{\text { berat sampel awal }} \times 100 \%$

3. Kadar abu

$\% \mathrm{Abu}=\frac{\text { gram abu }}{\text { berat sampel awal }} \times 100 \%$

4. Analisa Kadar Metoksil

$$
\text { Kadar metoksil }=\frac{\mathrm{mL} \mathrm{NaOH} \times \mathrm{N} \mathrm{NaOH} \times 31}{\text { miligram s ampel }} \times 100 \%
$$

5. Asam Galakturonat

$$
\% \text { Asam Galakturonat }=\frac{\mathrm{V} 1+\mathrm{V} 2 \times \mathrm{N} \mathrm{NaOH} \times 194}{\text { miligram sampel }} \times 100 \%
$$

\section{Hasil dan Diskusi}

\subsection{Pengaruh Konsentrasi Pelarut dan Waktu Ekstraksi terhadap Yield Pektin}

Pektin dalam jaringan tanaman terdapat sebagai protopektin yang tidak larut dalam air (insoluble) karena berada sebagai garam kalsium dan magnesium. Oleh karena itu, dilakukan hidrolisis protopektin dalam air yang diasamkan untuk mengubah protopektin menjadi pektin yang bersifat larut dalam air, dimana ion 
$\mathrm{H}^{+}$pada air akan menggantikan ion kalsium dan ion magnesium pada molekul protopektin. Dari penelitian yang dilakukan, didapatkan yield pektin yang berbeda - beda pada setiap perlakuan yang diberikan. Hasil persen yield pektin terhadap waktu ekstraksi diperlihatkan pada Gambar 3.

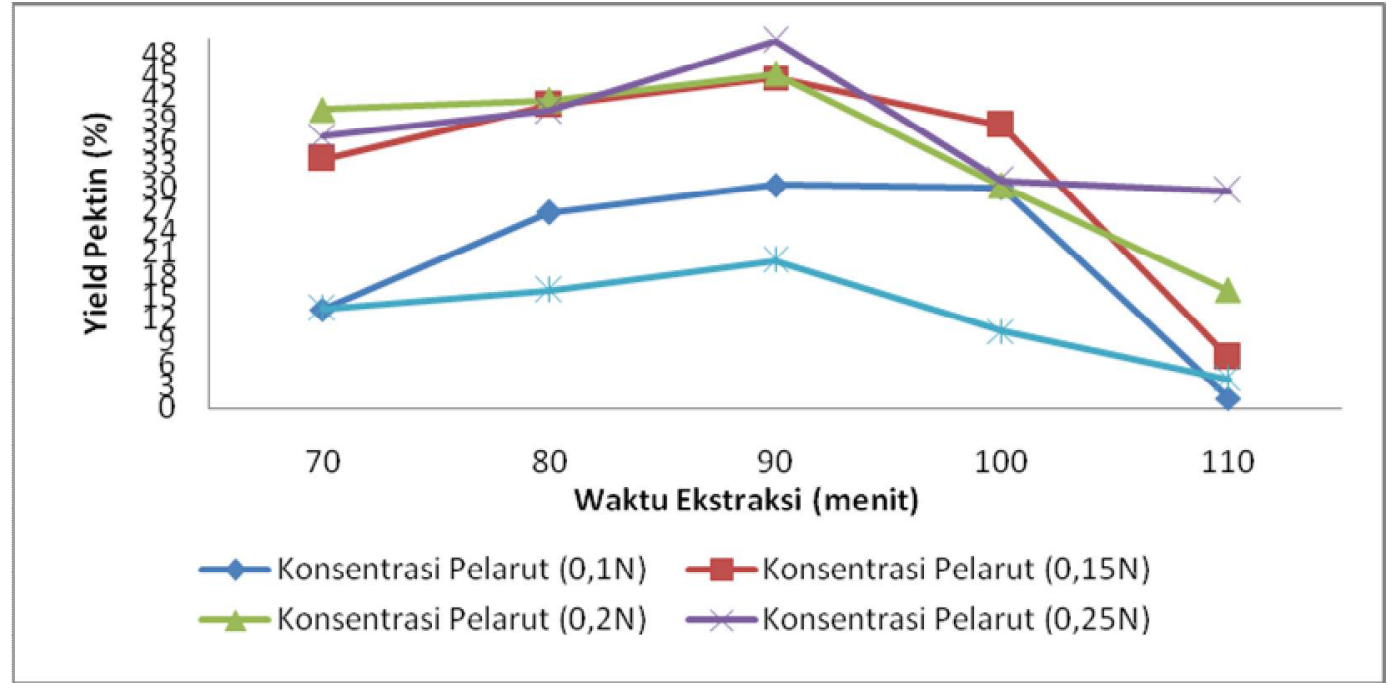

Gambar 3 Pengaruh Konsentrasi Pelarut dan Waktu Ekstraksi Terhadap Pektin

Yield pektin dari penelitian ini berkisar antara 1,39-50\%. Yield tertinggi diperoleh pada konsentrasi pelarut $0,25 \mathrm{~N}$ dan waktu 90 menit sedangkan yang terendah pada konsentrasi $0,1 \mathrm{~N}$ dan waktu 110 menit. Dari gambar 3.1 dapat dsimpulkan bahwa konsentrasi pelarut dan waktu ekstraksi berpengaruh nyata pada yield pektin yang dihasilkan. Semakin lama waktu ekstraksi maka pektin yang dihasilkan juga semakin banyak. Namun pada waktu ektraksi 110 menit, yield pektin menurun. Hal terjadi karena apabila waktu ekstraksi yang terlalu lama maka pelarut sudah dalam keadaan jenuh dan pektin sudah terdegredasi. Hal ini juga menunjukan bahwa telah tercapainya kondisi maksimum pada proses ekstraksi yaitu pada suhu 90 menit.

\subsection{Pelarut dan Waktu Ekstraksi terhadap Kualitas Pektin}

Kadar air bahan berpengaruh terhadap masa simpan. Kadar air yang tinggi menyebabkan kerentanan terhadap aktivitas mikroba. Dalam upaya memperpanjang masa simpan pektin, dilakukan pengeringan pada oven dengan 
suhu $45^{\circ} \mathrm{C}$ selama 8 jam. Pengeringan pada suhu rendah bertujuan untuk meminimalkan degradasi pektin. Hasil analisa kadar air dapat dilihat pada Gambar 3.

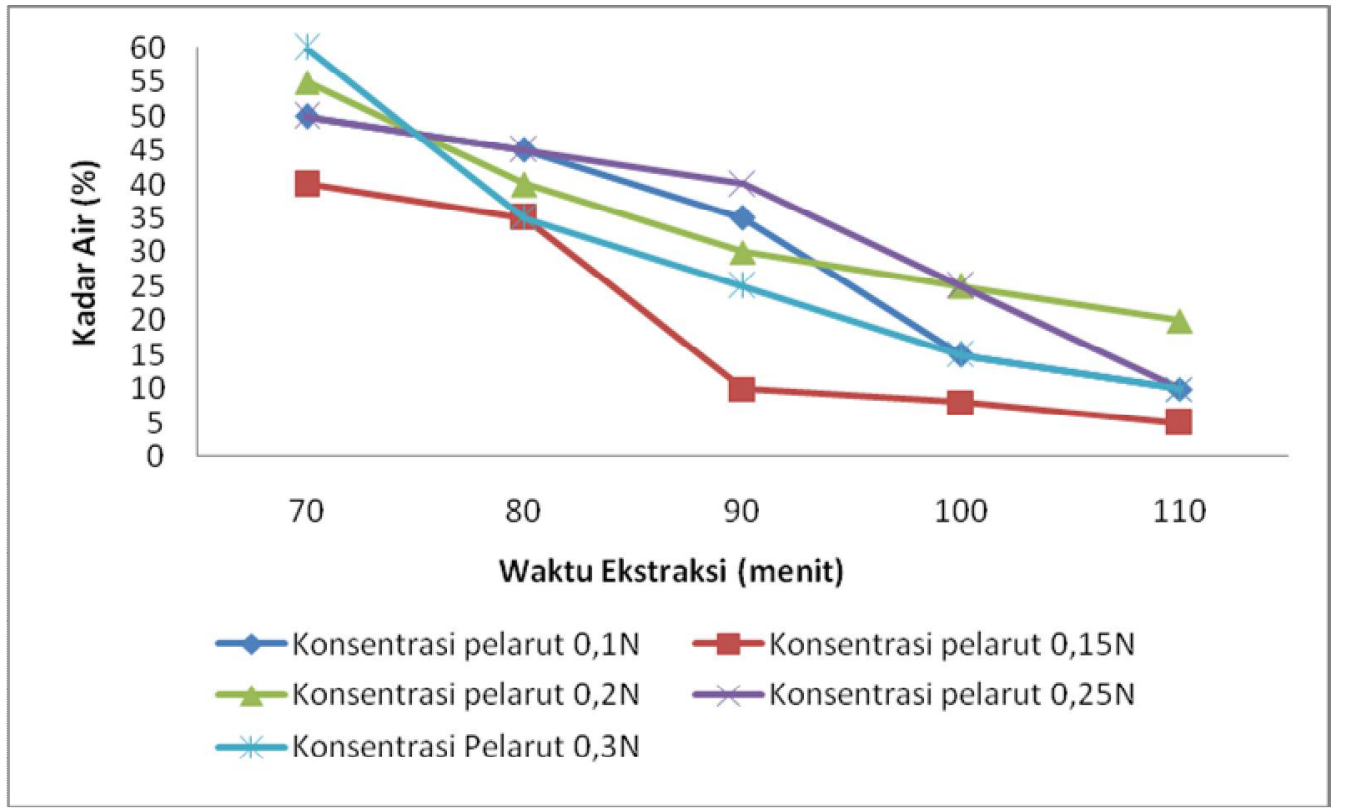

Gambar 3 Pengaruh Konsentrasi Pelarut dan Waktu Ekstraksi Terhadap Kadar Air

Dari gambar 3 dapat dilihat bahwa kadar air pektin yang didapat berkisar antara 5-60\%. Kadar air tinggi disebabkan oleh waktu pengovenan yang kurang lama sehingga penguapan air tidak berlangsung sempurna. Batas maksimum nilai kadar air yang diizinkan menurut IPPA adalah $12 \%$, hal ini menunjukan bahwa pektin yang dihasilkan belum sesuai dengan standar yang ada. Oleh karena itu perlu dilakukan pengeringan kembali.

\subsection{Kadar Abu}

Abu merupakan residu atau sisa pembakaran bahan organik. Kadar abu berpengaruh pada tingkat kemurnian pektin. Kadar abu pektin dapat dilihat pada Gambar 4. 


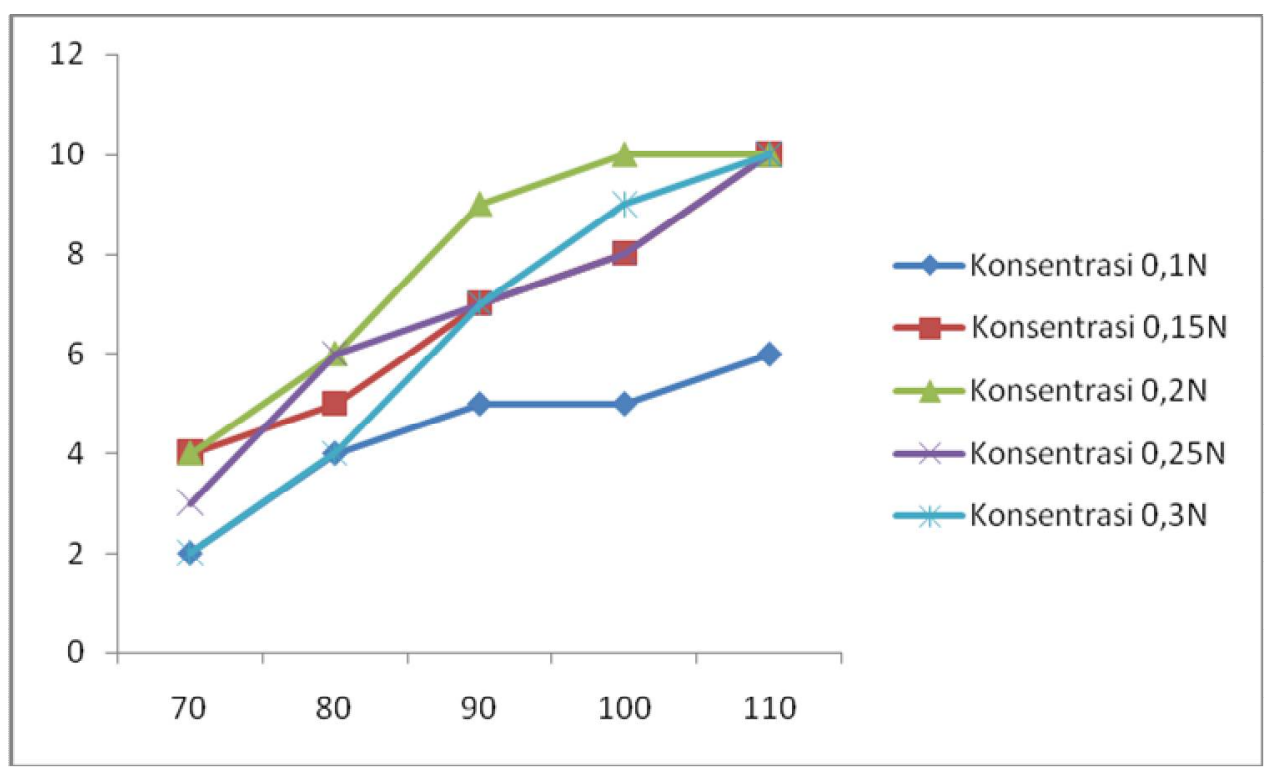

Gambar 4 Pengaruh Konsentrasi Pelarut dan Waktu Ekstraksi Terhadap Kadar $\mathrm{Abu}$

Dari gambar 4 dapat dilihat bahwa kadar abu yang didapatkan berkisar antara $2-10 \%$. Kadar abu yang rendah berarti tingkat kemurnian pektin lebih tinggi. Semakin lama waktu ektraksi maka kadar abu yang didapat semakin tinggi. Hal ini terjadi karena adanya reaksi hidrolisis protopektin. Hidrolisis protopektin menyebabkan bertambahnya kandungan kalsium dan magnesium yang merupakan mineral sebagai komponen abu.

\subsection{Kadar Asam Galakturonat}

Kadar galakturonat dan muatan molekul pektin memiliki peranan penting dalam menentukan sifat fungsional larutan pektin. Kadar galakturonat dapat mempengaruhi struktur dan tekstur dari gel pektin (Constenla dan Lozano, 2003). Tinggi rendahnya \% asam galakturonat terhadap waktu ekstraksi diperlihatkan pada Gambar 5.

Dari uraian gambar 5 dapat ditunjukan bahwa kadar asam galakturonat yang dihasilkan pada $0,3 \mathrm{~N}, 110$ menit lebih tinggi dari yang lainnya. Kadar asam galakturonat yang dihasilkan berkisar antara 4,268\%-65,96\%. Menurut standar yang telah ditetapkan, kadar asam galakturonat minimal 35\%. Kadar asam galakturonat yang memenuhi standar dalam penelitian ini didapat pada 
ekstraksi 0,3 N selama 70,80,90,100 dan 110 menit dan 0,25 $\mathrm{N}$ selama 110 menit.

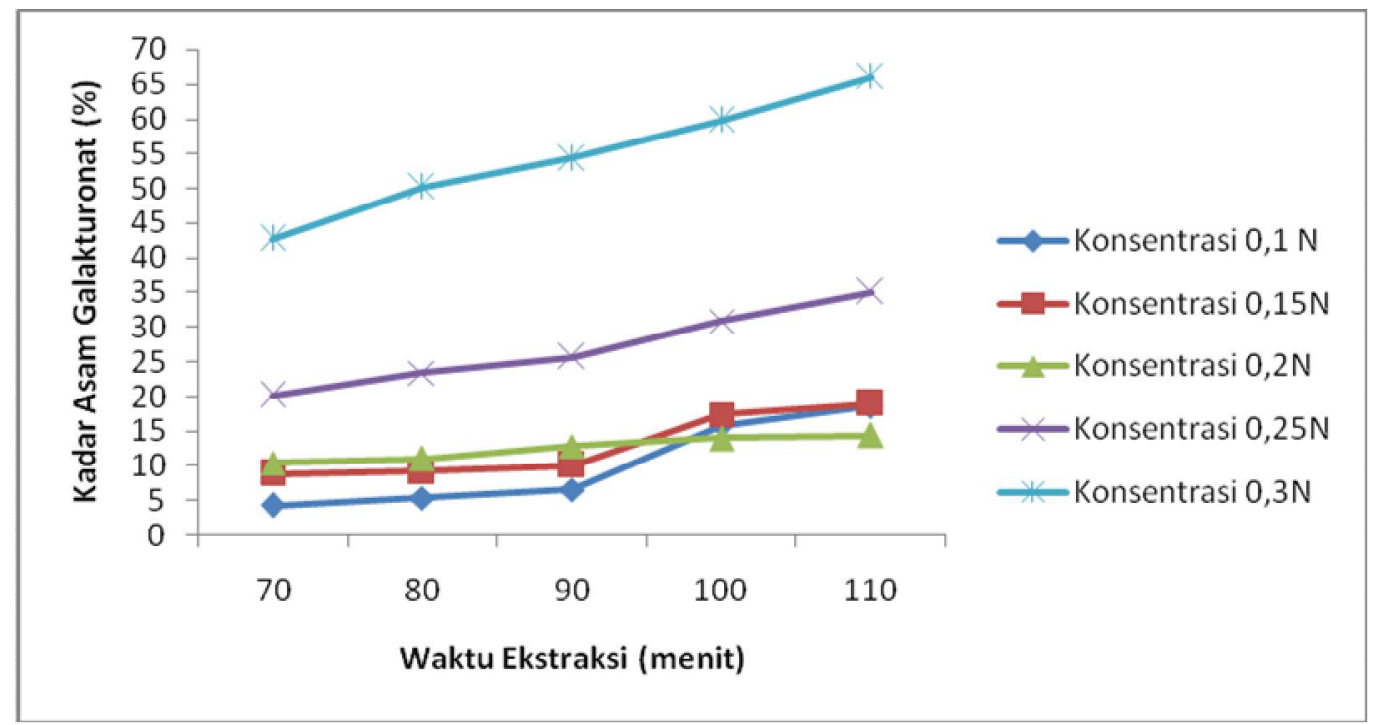

Gambar 5 Pengaruh Konsentrasi Pelarut dan Waktu Ekstraksi Terhadap Kadar Asam Galakturonat

\subsubsection{Kadar Metoskil}

Kadar metoksil pektin memiliki peranan penting dalam menentukan sifat fungsional larutan pektin dan dapat mempengaruhi struktur dan tekstur dari gel pektin (Constenla dan Lozano, 2003). Kadar metoksil pektin ampas jeruk dapat ditujukan pada Gambar 6.

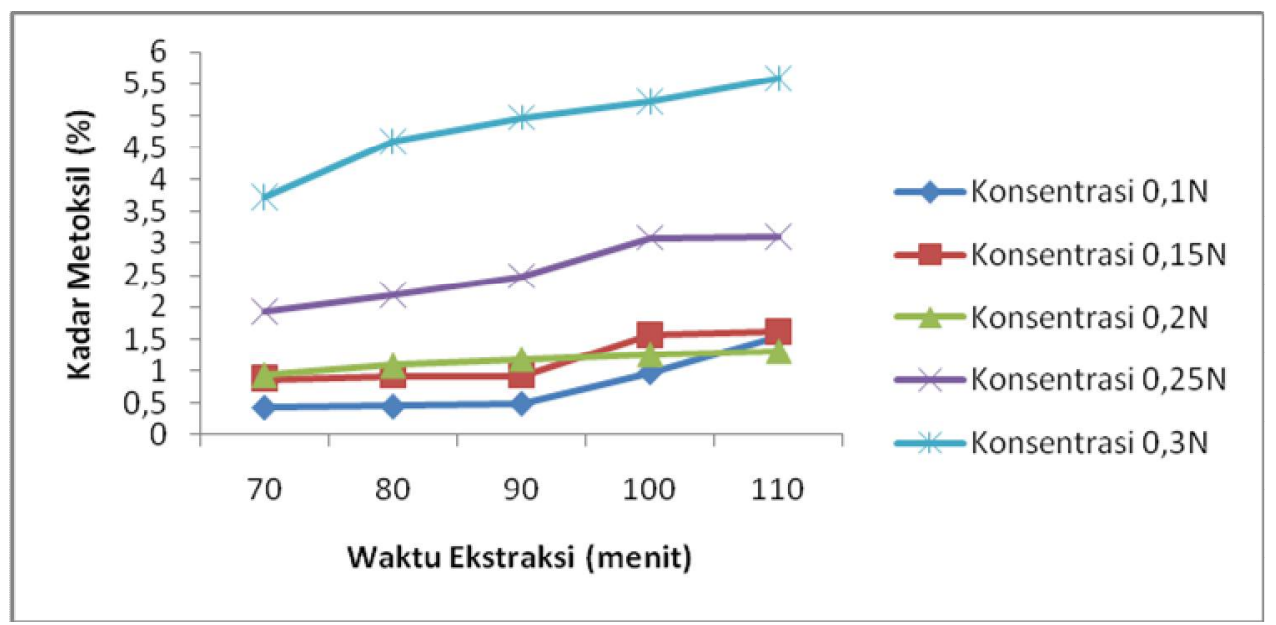

Gambar 6 Pengaruh Konsentrasi Pelarut dan Waktu Ekstraksi Terhadap Kadar Metoksil 
Dari gambar di atas dapat diperlihatkan bahwa kadar metoksil yang dihasilkan pada $0,3 \mathrm{~N}, 110$ menit lebih tinggi yaitu 5,58\%. Kadar metoksil pada penelitian ini berkisar antara 0,434\%-5,58\%. Menurut Hoejgaard (2004) berdasarkan kadar metoksil yang dihasilkan, jenis pektin ini merupakan pektin bermetoksil rendah karena kadarnya kurang dari 7\%. Hal ini menguntungkan karena pektin dapat langsung diproduksi tanpa melalui proses demetilasi. Kadar metoksil pektin akan semakin tinggi dengan meningkatnya waktu ektraksi. Hal ini disebabkan gugus karboksil bebas yang teresterifikasi semakin meningkat.

\section{Simpulan}

Dari hasil kajian dapat disimpulkan bahwa limbah tempurung kelapa dengan menggunakan getah rumbia sebagai perekat dapat dimanfaatkan menjadi briket arang. Ukuran partikel (mesh) dan berat perekat sangat mempengaruhi kualitas briket yang dihasilkan dari arang tempurung kelapa. Kondisi terbaik briket didapatkan pada ukuran partikel 80 mesh dan 25 gr perekat dengan nilai kalor yang dihasilkan $29327 \mathrm{kal} / \mathrm{gram}$.

Dalam pembuatan briket, moistur briket (kadar air) sangat dipengaruhi oleh perbandingan antara perekat dengan serbuk arang yang digunakan. Penggunaan kadar perekar 35 gr dalam serbuk arang 150 gram dengan ukuran serbuk arang 50 mesh menghasilkan kadar air yang paling rendah yaitu 7,4\%. Sedangkan untuk ukuran serbuk arang 80 mesh adalah $6,4 \%$.

\section{Daftar Pustaka}

1. Triono, A. 2006. Karakteristik Briket Arang Dari Campuran Serbuk Gergajian Kayu Afrika (Maesopsis eminii Engl) dan Sengon (Paraserianthes falcataria L. Nielsen) dengan Penambahan Tempurung Kelapa (Cocosnucifera L). Skripsi Strata-1 Institut Pertanian Bogor. Bogor.

2. Sutiyono, 2002. Pembuatan Briket Arang dari Tempurung Kelapa dengan Bahan Pengikat Tetes Tebu dan Tapioka. Jurnal Kimia dan Teknologi. Surabaya: Jurusan Teknik Kimia Fakultas Teknologi Indutri-UPN Veteran.

3. Lestari, L., Aripin, Yanti, Zainudin, Sukmawati, Marliani. 2010. Analisis Kualitas Briket Arang Tongkol Jagung Yang Menggunakan Bahan Perekat Sagu dan Kanji, Jurnal aplikasi fisika, 6(2): 93-96. 
4. Obi, O. F. 2015. Evaluation of the Effect of Palm Oil Mill Sludge on the Properties of Sawdust Briquette. Renewable and Sustainable Energy Reviews $52: 1749-1758$.

5. Santosa, R. Mislaini, dan S.P. Anugrah. 2010, Studi Variasi Komposisi bahan Penyusun Briket dari Kotoran Sapi dan Limbah Pertanian, Jurusan Teknik Pertanian, Fakultas Teknologi Pertanian Universitas Andalas.

6. Maryono, Sudding dan Rahmawati. 2013. Pembuatan dan Analisis Mutu Briket Arang Tempurung Kelapa Ditinjau dari Kadar Kanji. Jurnal Chemica. 14 (1): $74-83$.

7. Hapis dan Bisrul. 2008. Karakteristik Pembakaran Briket Cangkang Kerniri: Pengaruh Persentase Arang. Jurusan Teknik Mesin Fakultas Teknik Universitas Negeri Medan.

8. Ristianingsih, Y., A. Ulfa, dan R.K.S. Syafitri. 2015. Pengaruh Suhu dan Konsentrasi Perekat Terhadap Karakteristik Briket Bioarang Berbahan Baku Tandan Kosong Kelapa Sawit dengan Proses Pirolisis, Konversi, 4 (2):16-22. 